\title{
Synaptic Homeostasis and Its Immunological Disturbance in Neuromuscular Junction Disorders
}

\author{
Masaharu Takamori \\ Neurological Center, Kanazawa-Nishi Hospital, Kanazawa, Ishikawa 920-0025, Japan; \\ m-takamori@vanilla.ocn.ne.jp; Tel.: +81-76-233-1811; Fax: +81-76-221-8603 \\ Academic Editor: David Beeson \\ Received: 21 February 2017; Accepted: 19 April 2017; Published: 24 April 2017
}

\begin{abstract}
In the neuromuscular junction, postsynaptic nicotinic acetylcholine receptor (nAChR) clustering, trans-synaptic communication and synaptic stabilization are modulated by the molecular mechanisms underlying synaptic plasticity. The synaptic functions are based presynaptically on the active zone architecture, synaptic vesicle proteins, $\mathrm{Ca}^{2+}$ channels and synaptic vesicle recycling. Postsynaptically, they are based on rapsyn-anchored nAChR clusters, localized sensitivity to ACh, and synaptic stabilization via linkage to the extracellular matrix so as to be precisely opposed to the nerve terminal. Focusing on neural agrin, Wnts, muscle-specific tyrosine kinase (a mediator of agrin and Wnts signalings and regulator of trans-synaptic communication), low-density lipoprotein receptor-related protein 4 (the receptor of agrin and Wnts and participant in retrograde signaling), laminin-network (including muscle-derived agrin), extracellular matrix proteins (participating in the synaptic stabilization) and presynaptic receptors (including muscarinic and adenosine receptors), we review the functional structures of the synapse by making reference to immunological pathogenecities in postsynaptic disease, myasthenia gravis. The synapse-related proteins including cortactin, coronin-6, caveolin-3, doublecortin, R-spondin 2, amyloid precursor family proteins, glia cell-derived neurotrophic factor and neurexins are also discussed in terms of their possible contribution to efficient synaptic transmission at the neuromuscular junction.
\end{abstract}

Keywords: neuromuscular junction; agrin; Wnts; muscle-specific tyrosine kinase; low-density lipoprotein receptor-related protein 4; laminins; myasthenia gravis; nicotinic acetylcholine receptor; muscarinic acetylcholine receptor; adenosine receptor

\section{Introduction}

The neuromuscular junction is a cholinergic synapse where agrin, Wnts, low-density lipoprotein receptor related-protein 4 (Lrp4), muscle-specific tyrosine kinase (MuSK) and extracellular matrix proteins are required for the complex differentiation and precise alignment of the pre- and postsynaptic structures. The signalings via agrin/Lrp4-MuSK ( $\operatorname{Ig} 1 / 2$ domains, participating in the innervated stage of muscle) and Wnt/Lrp4-MuSK (cysteine-rich domain, participating in the non-innervated stage of muscle and axonal guidance) contribute to nicotinic acetylcholine receptor (nAChR) clustering, trans-synaptic communication and synaptic stability [1,2]. In myasthenia gravis (MG) mainly caused by the $\mathrm{nAChR}$ antibodies, a proportion of the patients harbor antibodies recognizing MuSK and Lrp4 which are responsible for pre- and postsynaptic impairments and contributive, at least in part, to a defect in ACh-release upregulation to compensate for postsynaptic dysfunction [3-10]. The following points will be emphasized below: (1) heterogeneity of postsynaptic MuSK and Lrp4 antibodies in their binding to functional domains which are responsible for pre- and postsynaptic functions; (2) the key molecular mediators such as Wnts, MuSK and Lrp4 act bidirectionally to form pre- and postsynaptic architectures; (3) the compensatory upregulation of ACh quantal release depending on the modulation 
via muscarinic and adenosine receoptors in the nerve terminal; and (4) Laminin-network and synaptic collagens (linking to MuSK) participating in synaptic stabilization.

\section{Postsynaptic Organizations, Centered on MuSK, Lrp4 and Synapse-Related Proteins}

MuSK is uniquely positioned as a key protein in the neuromuscular junction (NMJ). The ectodomain of muscle-derived MuSK consists of four immunoglobulin-like domains (Ig domains). The cysteine-rich domain (CRD, Ig4 domain) interacts with Wnts and thereby operates on synaptic function via the Wnts non-canonical signaling pathway $[1,2,11-18]$. Wnts belong to the Wingless-type mouse mammary tumor virus (MMTV) integration site family of glycoproteins which are released from motor neurons or derived from muscles; 19 different Wnt molecules exist in mice and humans [2]. The interaction of MuSK CRD with Wnts leads to nAChR clustering at the non-innervated stage of muscle through dishevelled scaffolding protein (Dvl) for the prepatterning of nAChR clusters (nAChR microcluster formation at the central part of muscle membrane where incoming axons are guided) and converges on the neural agrin-mediated signaling (Figure 1). The first and second immunoglobulin-like domains (Ig1/2 domains) conduct the neural agrin signal to form full-sized nAChR clusters in the innervated stage of muscle [1,2,19-22] (Figure 1). The nAChR clusters are anchored in the muscle membrane by rapsyn which is immobilized by MuSK-linking heat-shock proteins $[23,24]$ (Figure 1). The negative regulation by the muscle-derived Wnt (such as Wnt3a)-canonical pathway via $\beta$-catenin/glycogen synthese kinase-3 reduces the expression of rapsyn, resulting in the reduction of agrin-mediated AChR clustering; this regulation maintains balance with the positive regulatory neuron-derived Wnt (such as Wnt3) and thereby helps to sculp the mature synaptic architecture; Wnt3 activates Rac1 in a more efficient usage than agrin which preferentially increases Rho activity $[15,17]$. The muscle-derived Lrp4 contributes to $\mathrm{nAChR}$ cluster formation by acting as the receptor for both Wnts and agrin at both non-innervated and innervated muscle membranes; Lrp4 can activate MuSK even without agrin [25-29] (Figure 1). In the molecular structure of Lrp4, the first propeller domain interacts with agrin [20]; in the third propeller domain, its edge part mediates the MuSK signaling and its central part mediates the Wnt signaling [30]. Adenomatous polyposis coli (APC) contributes to nAChR clustering and supports a cross-talk between agrin- and Wnt-mediated signaling pathways by coordinating the function of actin and the microtubule cytoskeleton during synapse formation [31].

The MuSK ectodomain also plays a role in the interaction of MuSK with matrix proteins [32-36], such as collagen $Q /$ perlecan [37], biglycan [38,39] and cortactin [40], to contribute to postsynaptic stabilization in cooperation with laminin-network (including laminins $\alpha 4, \alpha 5$ and $\beta 2$, muscle-derived agrin and dystroglycans which link to rapsyn and utrophin) [32-36,41-44] (the right yellow frames in Figure 1). The synaptic collagens (such as IV and XIII), nidogen-2 and rapsyn-interacting molecules (such as heat-shock proteins, $\alpha$-actinin and calpain) are important for the maintenance of the neuromuscular junction [1,2,36]. Intracellularly, the interaction of neuregulin 1 with ErbB receptor (receptor tyrosine kinase of EGF, epidermal growth factor, receptor family) activates MuSK through the adaptor protein erbin to increase the tyrosine phosphorylation of MuSK and thereby modulate MuSK-dependent $n A C h R$ clustering $[45,46]$ (Figure 1). In addition, the neuregulin 1-ErbB receptor interaction contributes to the stabilization of the postsynaptic apparatus through the phosphorylation of $\alpha$-dystrobrevin [47] (Figure 1). In another intracellular signaling cascade, Dok-7 (downstream of kinase 7) forms a dimeric unit to dimerize and activate MuSK $[48,49]$ and also recruits two adaptor proteins, Crk and Crk-L (CT10 regulators of kinase) which play an early role in the rapsyn-anchored nAChR cluster formation [50]. Downstream effects of Crk-L (Sorbs1/2) on cytoskeletal dynamics stabilize the postsynaptic organization [51] (Figure 1).

\section{Trans-Synaptic Communication}

The trans-synaptic communication is mediated via the Wnts canonical signaling by way of Wnts/MuSK CRD/Dvl/inhibition of glycogen synthese kinase $3 \beta / \beta$-catenin/Slit 2 in the muscle [52-54] (left upper part of Figure 1). This signaling leads to presynaptic differentiation to 
localize active zone proteins, synaptic vesicle proteins and $\mathrm{Ca}^{2+}$ channels at the nerve terminal, thereby conditioning the release-ready ACh-containing vesicles [55-59]. Besides the Wnts canonical signaling, muscle-derived Lrp4 interacts with an Lrp4-binding protein in motor neurons and acts as a retrograde signal to promote presynaptic differentiation [60,61] (left upper part of Figure 1). In addition, the muscle-derived synaptic organizers, laminins $\alpha 4, \alpha 5$ and $\beta 2$, contribute to organization of the presynaptic active zone structure for ACh release [41-44] (right upper part of Figure 1). Laminin $\beta 2$ tethers $\mathrm{P} / \mathrm{Q}$ - and $\mathrm{N}$-type voltage-gated $\mathrm{Ca}^{2+}$ channels (VGCCs) to the presynaptic active zone and cytoskeletal elements, thereby stabilizing the active zone structure for ACh release [41,42]. In the molecular structure of P/Q-type VGCC $\alpha 1$-subunit, laminin-binding domain [42] corresponds to the region that we determined the S5-S6 linker of domain III as a major focus both of the antibodies in patients with Lambert-Eaton myasthenic syndrome (LEMS, an autoimmune presynaptic disease caused mainly by antibodies against P/Q-type VGCC and partly by antibodies against synaptotagmin 1) and in the induction of LEMS animal model (active immunization model) [62].

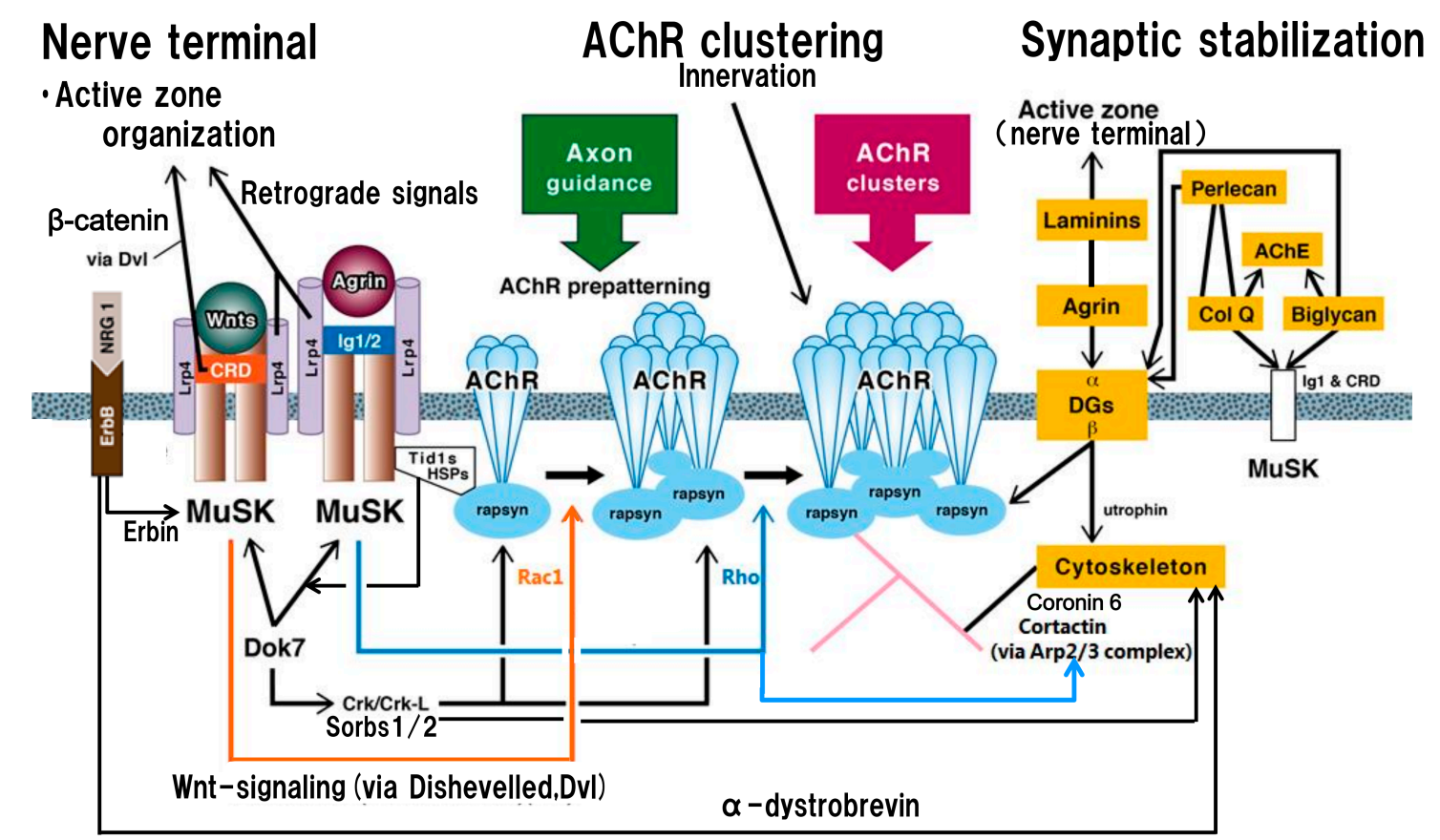

Figure 1. Schematic presentation of the postsynaptic structure and function on the basis of acetylcholine receptor clustering centered on agrin- and Wnt-signalings, trans-synaptic communication and synaptic stabilization. In the postsynaptic membrane, nicotinic acetylcholine receptors (nAChRs) are aggregated in the non-innervated stage via Wnts-MuSK cysteine-rich domain (CRD)-dishevelled protein signaling pathway to form $n A C h R$ microclusters (AChR prepatterning: located in the central part of the muscle membrane where incoming axons are guided) (orange line with arrow; via activation by Rac1), and in the innervated stage via agrin-MuSK immunoglobulin-like domains 1 and 2 (Ig1/2) signaling pathway to form full-sized nAChR clusters (blue line with arrow; via activation by Rho). The nAChR clusters in non-innervated and innervated stages are anchored by rapsyn (immobilized by heat-shock proteins, HSPs, including tumorous imaginal disc 1 short form, Tid1s, which belongs to HSP40 family) at the postsynaptic membrane. The kinase activity and subsequent downstream signalings by the intracellular tyrosine kinase domain of MuSK, located after the transmembrane segment, are crucial for the formation and maintenance of the neuromuscular junction. The low-density lipoprotein receptor-related protein 4 (Lrp4) plays an essential role in agrin- and Wnts-signaling pathways as the receptor for both signals. In the molecular structure of Lrp4, the first propeller domain interacts with agrin; in the third $\beta$-propeller domain, its edge part mediates the MuSK signaling and its central cavity mediates the Wnt signaling. As the trans-synaptic communication, the signaling mediated by Wnts-MuSK CRD contributes to the 
retrograde signal from muscle to nerve (Wnt canonical pathway via dishevelled protein (Dvl) and $\beta$-catenin), leading to presynaptic differentiation to localize active zone proteins for efficient synaptic transmission (left upper part). Others participating in the trans-synaptic communication are reviewed in detail in the text; among them, the retrograde signal of Lrp4 originates from its eight low-density lipoprotein a (LDLa) repeats to induce clustering of synaptic vesicle and active zone proteins [60] (left upper part). In addition, as shown in the right part (a part of synaptic stabilization), Laminins conduct the retrograde signal to firm the active zone architecture for sufficient synaptic transmission. Intracellularly, Dok7 (downstream of kinase 7) and neuregulin 1 (NGR1)-ErbB receptor (receptor tyrosine kinase of EGF, epidermal growth factor, receptor family) (mediator: Erbin) interaction activate intracellular MuSK tyrosine kinase domain for nAChR cluster formation (left part); also, they contribute to postsynaptic stability via respective downstream effectors. The mediator for Dok7 signal is Sorbs1/2 (downstream effectors of CT10 regulators of kinase (Crk/Crk-L)); the mediator for NGR1-ErbB receptor interaction is $\alpha$-dystrobrevin (both are indicated by long black lines from left to right with arrows). As shown in the right part (yellow frames) of the figure, the stability of the neuromuscular junction including AChR clusters, MuSK and acetylcholinesterase (AChE) in the postsynaptic membrane is modulated by the extracellular matrix proteins (collagen $Q(\mathrm{Col} Q)$, perlecan, biglycan (glycosaminoglycan-binding form) and dystroglycans (DGs)), which participate in cytoskeletal dynamics. In addition, the postsynaptic structure is stabilized by the laminin-network including laminins, muscle agrin and DGs. The transmembrane dystroglycan ( $\beta$-type) binds to rapsyn for anchoring AChR clusters at the postsynaptic membrane and also link utrophin to cytoskeleton for synaptic stability. Additionally, Col Q (C-terminus) and biglycan (non-glycanated form) bind both MuSK extracellular domains (Ig1 and CRD), leading to their implication in reinforcing a functional bridge between the agrin-signaling and the Wnt-signaling. Cortactin acts as a tyrosine kinase substrate and also a regulator of actin polymerization via actin-related proteins 2/3 complex (Arp2/3 complex); its tryrosine phosphorylation is enhanced by agrin/MuSK signaling (as indicated by blue line from central to right with arrow). Coronin 6 contributes to firm nAChR clustering via the modulation of actin dynamics.

Presynaptically, the $\alpha 2 \delta-3$ auxiliary subunit of the presynaptic $\mathrm{Ca}^{2+}$ channel is required for rapid homeostatic signaling which controls the active zone protein-dependent readily releasable ACh-containing vesicle pool [63]. Postsynaptically, in the innervated stage of muscle, ACh stimulates cyclin-dependent kinase 5 (postsynaptic serine/threonine kinase) to interact with nestin and thus inhibits the dispersion of AChR clusters which are not stabilized by agrin $[1,64]$.

In view of these observations, particularly paying attention to the roles of MuSK in Wnts/MuSK CRD non-canonical and canonical pathways, we assayed the serum samples from 43 nAChR antibody-negative MG patients using the recombinant proteins expressed in HEK 293F cells as antigens [65]. The result showed that MuSK Ig1/2 antibodies were positive in 33 patients, 10 of whom (30\%) were also positive for MuSK CRD antibodies (Table 1). The longitudinal epitope mapping study in $53 \mathrm{MuSK}$ antibody-positive MG patients by the European research group showed that $22.6 \%$ of the patients were positive for MuSK CRD antibodies, although they emphasized the MuSK Ig1 domain as the main immunogenic region [66]. Although no patients were positive for MuSK CRD antibodies alone [65], the Japanese research group studied five MuSK antibody-positive patients and reported that the MuSK antibodies recognized the MuSK Ig1 domain and MuSK CRD in three patients and only MuSK CRD in two other patients [67]. It seems likely that the MuSK antibodies have heterogeneity in their binding to functional domains responsible for pre- and postsynaptic functions. To determine the functional significance of MuSK CRD (Frizzled-like domain) in the NMJ, the French research group showed that the CRD deletion of MuSK in mice caused exuberant axonal growth bypassing nAChR clusters and decreased synaptic vesicle density (presynaptic impairment), and a drastic deficit in $\mathrm{nAChR}$ clustering (postsynaptic impairment) [68]. They also suggested an implication of MuSK CRD in the Wnt-canonical signaling by demonstrating that these pre- and post-synaptic impairments were rescued by lithium chloride which acts as an inhibitor of the glycogen synthese kinase- 3 and an activator of the Wnt/ $\beta$-catenin signaling [68]. The New York research group and associates have 
recently proposed that dependently on species, the prepatterning of AChR clusters is influenced by an additional presence of kringle domain in the MuSK extracellular region [69]. The pathogenic variety of MuSK antibodies is further suggested by the fact that the collagen Q-MuSK interaction is blocked by MuSK antibodies [70], leading to hypersensitivity of the muscle membrane to ACh. This is based on the evidence that the synaptic anchorage of acetylcholinesterase (AChE) by collagen $Q$ partly depends on the association of collagen Q with MuSK [37,71]. In fact, the MuSK MG animal models showed the electrophysiological finding characterized by slow miniature end-plate potential kinetics and hypersensitivity to AChE inhibitors [4,5]. In coordination with MuSK, the fetal nAChR $\gamma$-subunit [72] (antibodies to this subunit are detected in fetal nAChR inactivation syndrome, FARIS [73]), and the L-type $\mathrm{Ca}^{2+}$ channel dihydropyridine receptor [74] (antibodies to this receptor are detected in some MG patients [75]) are important in muscle prepatterning of AChR clusters which participate in axonal guidance to the muscle $[1,2,14,17,29]$.

Table 1. Study of antibodies against muscle specific tyrosine kinase (MuSK) extraceullar segment (immunoglobulin-like 1 and 2 (Ig1/2) domains and cysteine-rich domain (CRD)): clinical and immunological profiles of 33 patients positive for MuSK (extracellular full-length) antibodies and negative for nicotininc acetylcholine receptor (AChR) antibodies.

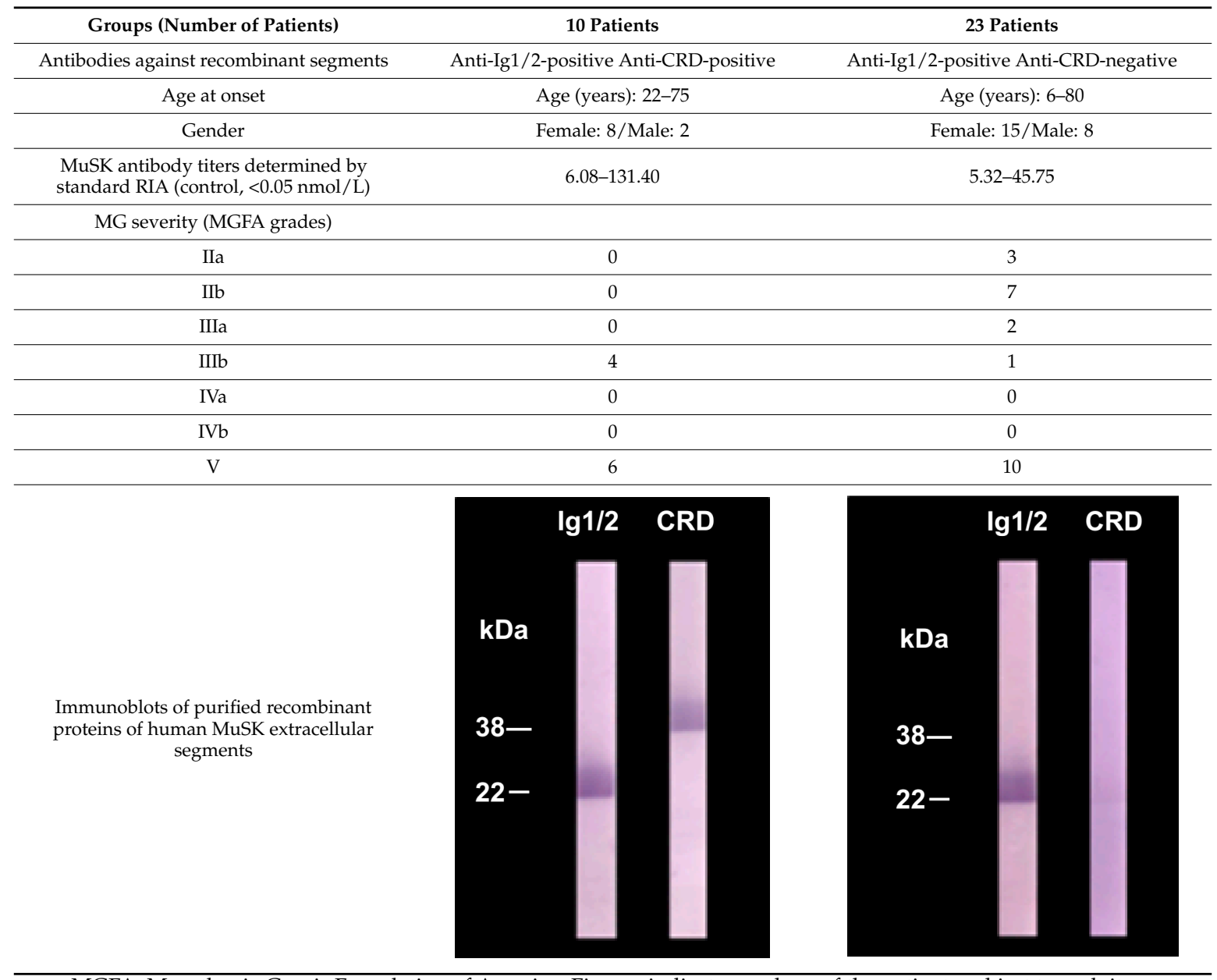

MGFA: Myasthenia Gravis Foundation of America. Figures indicate numbers of the patients subject to each item. The study collected 43 anti-AChR-negative patients, 10 of whom were negative for antibodies determined by both the standard radioimmunoassay (RIA, extracellular full-length of MuSK used as antigen) and the present study (Ig1/2 domains and CRD of MuSK used as antigens). Immunoblotting was done using purified recombinant protein of human MuSK Ig1/2 domains and CRD. Immunostained reactivity was tested with serum samples (1:500 dilution) from myasthenia gravis patients at $5 \mu \mathrm{g}$ recombinant protein/lane; $22 \mathrm{kDa}$ and $38 \mathrm{kDa}$ immunostained bands were visualized as anti-Ig1/2 domains and anti-CRD, respectively ; these were confirmed by using mouse anti-human monoclonal antibodies, respectively [65]. 
The electrophysiological study in MG with nAChR antibodies reported that compensatory ACh-release is upregulated but cannot be sustained at the high-frequency of nerve stimulation, possibly because of reduced pool of releasable ACh-containing vesicles $[9,76]$. In the nerve terminal, the homeostatic signal targets both $\mathrm{Ca}^{2+}$ influx and the release-ready vesicle pool [77]. During high frequency transmission, however, the early enhanced ACh quantal release causes the homeostatic upregulation of release based on $\mathrm{Ca}^{2+}$-dependent docking/priming of a small homeostatic reserve pool of vesicles (different from the pool of vesicles normally released); once the small pool of vesicles is depleted by the block of vesicle refilling, this homeostatic upregulation of ACh quantal release is no longer observed [78]. From the viewpoints of presynaptic autoreceptors, it should be taken into consideration that the mechanism underlying the interplay between presynaptic muscarinic and adenosine receptors controls $\mathrm{ACh}$ release in mammalian motor nerve terminals depending on the nerve stimulation paradigm; the A2A adenosine receptor (operating $\mathrm{Ca}^{2+}$ influx via L-type channels) plays a key role during long-lasting and/or high-frequency nerve activity [79-84], a situation that is impaired in toxin-induced myasthenia gravis and dysfunctional in experimental autoimmune myasthenia gravis $[85,86]$.

\section{Agrin, Cortaction and the Other Synapse-Related Proteins Contributing to the Modulation of Pre- and Postsynaptic Organizations}

Agrin antibodies have been detected in MG patients including four triple negative MG patients (i.e., no detectable nAChR, MuSK or Lrp4 antibodies) $[87,88]$. The muscle agrin participates in postsynaptic stabilization as a protein included in laminin-network via its laminin-like G2 domain and $\alpha$-dystroglycan. The neural agrin has amino acid insertion at two splicing sites and functions via its laminin-like G3 domain, thereby contributing to Lrp4/MuSK-mediated nAChR clustering at the postsynaptic membrane [21,89-92]. Besides the immunological implication, the dysfunction of agrin may be brought about by degradation due to the high level of matrix metalloproteinases (membrane-anchored extracellular proteases) [93] which was detected in sera of some MG patients [94,95]; this biological event could underlie muscle weakness in these reported patients. On the other hand, the expression of agrin in the nerve is upregulated by Brain-derived neurotrophic factor (BDNF)-Receptor tyrosine kinse B (TrkB) interaction which is brought about via $\mathrm{Ca}^{2+}$-response in the presynaptic Schwann cells containing transforming growth factor (TGF)- $\beta 1$, thereby promoting agrin-induced $\mathrm{nAChR}$ cluster formation [96,97]. In addition to the promotion of presynaptic vesicle recycling [98], the effects of BDNF in the synapse are regulated by way of Wnt canonical signaling pathway [99] and activated by $\beta 2$-adrenoceptor agonists (via intracellular signaling pathways, perhaps including the cyclic adenosine monophosphate, cAMP/protein kinase A/cAMP-responsive element-binding protein pathway) to maintain the structural and functional integrity of motor endplates [100]. The therapeutic pre- and postsynaptic benefits of $\beta$-adrenoceptor agonists (salbutamol and ephedrine) have been reported in MuSK MG animal models [101], neonatal myasthenia gravis (FARIS, caused by fetal AChR $\gamma$-subunit antibodies [72,73]) [102] and MG patients with nAChR antibodies [103] as well as various types of congenital myasthenic syndrome [104,105] including the patients suffering from mutations in MuSK [106] and Lrp4 [107].

Cortactin antibodies are also suggested to be involved in underlying autoimmune mechanism in MG $[108,109]$. Cortactin acts as a protein that is a tyrosine kinase substrate and a regulator of actin polymerization; its tyrosine phosphorylation is enhanced by agrin, suggesting that a function of phosphorylation-dependent cortactin signaling downstream from agrin/MuSK promotes actin polymerization via actin-related proteins $2 / 3$ complex (Arp2/3 complex) and stabilizes AChR clusters at the postsynaptic membrane [40] (right part of Figure 1). Cortactin also expresses in the presynaptic side [110] and acts as a presynaptic effector molecule depending on the Wnt-signaling in Drosophila neuromuscular junction [111]. This may be worth studying in vertebrates. In fact, cortactin antibodies were found in a patient with presynaptic disease, LEMS [108]. 
The following synapse-related proteins may require a consideration for the synaptic organization and trans-synaptic communication although they have not been proven as immunological targets. The coronin- 6 regulates $\mathrm{AChR}$ clustering through modulating the interaction between $\mathrm{AChR}$ and the actin cytoskeletal network [112]. The caveolin-3 is a MuSK kinase domain-binding protein that participates in agrin-induced phosphorylation and activation of MuSK, thereby driving nAChR clustering [113]. The microtubule-associated protein doublecortin, expressed in motor neurons and skeletal muscles, normally limits axonal growth following establishment of synaptic contact with the postsynaptic element to orderly form the pre- and postsynaptic morphology [114]. The R-spondin 2 (Rspo2), highly expressed in motor neurons and reactive with leucine-rich repeat-containing G-protain coupled receptor 5 (Lrg5, expressed in skeletal muscles and enriched in the neuromuscular junction), acts as the Wnt-dependent (via Lrp4 and MuSK) and agrin-independent regulator of nAChR clustering, and also has an effect on synaptic vesicle recycling and number of active zones in the nerve terminal [115]. This biological signal indicates that Rspo2-Lrg5 interaction plays a role in precise apposition of pre- and post-synaptic components for the synaptic transmission through the Wnt-signaling pathway [115]; the signal may be conducted via the canonical pathway including $\beta$-catenin [116]. Amyloid precursor protein (APP) and APP-like protein, well known in the pathogenesis of Alzheimer's disease, participate in nAChR clustering via the Lrp4-MuSK signal in cooperation with agrin-mediated signal and also contribute to the presynaptic differentiation of the neuromuscular junction [117-120]. The density of ACh-containing vesicles mediated by APP at the presynaptic site is modulated by glia cell-derived neurotrophic factor (GDNF) expressed in muscle cells [121], the neuronal receptor of which is Ret tyrosine kinase [122]. APP family proteins contribute to synaptic plasticity in not only the central nervous system but also the neuromuscular junction. Shown in the central nervous system is that linking of presynaptic neurexins to postsynaptic neuroligins acts for the synaptic cell-adhesion and thereby mediates signaling across the synapse [123].

\section{Conclusions}

The present review sheds light on the molecular mechanisms that mediate the formation, stabilization and maintenance of the neuromuscular junction and trans-synaptic communication. They are based on the key molecular mediators including agrin, Wnts, Lrp4, MuSK, laminins, extracellular matrix and presynaptic receptors (including muscarinic and adenosine receptors). Insight into the functional structures organized by the synaptic and peri-synaptic proteins will foster further approach to search for new antigenic targets in immunological diseases, and also will be informative to the mutations causative of congenital myasthenic syndromes. An understanding of complex molecular mechanisms will potentially contribute to the development of target-specific therapeutic approaches to NMJ disorders.

Conflicts of Interest: The author declares no conflicts of interest.

\section{References}

1. Shi, L.; Fu, A.K.Y.; Ip, N.Y. Molecular mechanisms underlying maturation and maintenance of the vertebrate neuromuscular junction. Trends Neursci. 2012, 35, 441-453. [CrossRef] [PubMed]

2. Wu, H.; Xiong, W.C.; Mei, L. To build a synapse: Signaling pathways in neuromuscular junction assembly. Development 2010, 137, 1017-1033. [CrossRef] [PubMed]

3. Plomp, J.J.; van Kempen, G.T.; de Baets, M.B.; Graus, I.M.; Kuks, J.B.; Molenaar, P.C. Acetylcholine release in myasthenia gravis: Regulation at single end-plate level. Ann. Neurol. 1995, 37, 627-636. [CrossRef] [PubMed]

4. Klooster, R.; Plomp, J.J.; Huijbers, M.G.; Niks, E.H.; Straasheijm, K.R.; Detmers, F.J.; Hermans, P.W.; Sleijpens, A.; Verrips, A.; Losen, M.; et al. Muscle-specific kinase myasthenia gravis IgG4 autoantibodies cause severe neuromuscular junction dysfunction in mice. Brain 2012, 135 Pt 4, 1081-1101. [CrossRef] [PubMed] 
5. Viegas, S.; Jacobson, L.; Waters, P.; Cossins, J.; Jacob, S.; Leite, M.I.; Webster, R.; Vincent, A. Passive and active immunization models of MuSK-ab positive myasthenia: Electrophysiological evidence for pre and postsynaptic defects. Exp. Neurol. 2012, 234, 506-512. [CrossRef] [PubMed]

6. Koneczny, I.; Stevens, J.A.; de Rosa, A.; Huda, S.; Huijbers, M.G.; Saxena, A.; Maestri, M.; Lazaridis, S.K.; Zisimopoulou, P.; Tzartos, S.; et al. IgG4 autoantibodies against muscle-specific kinase undergo Fab-arm exchange in myasthenia gravis. J. Autoimmun. 2017, 77, 104-115. [CrossRef] [PubMed]

7. Hijbers, M.G.; Zhang, W.; Klooster, R.; Niks, E.H.; Friese, M.B.; Straasheijm, K.R.; Thijssen, P.E.; Vrolijk, Z.H.; Plomp, J.J.; Vogels, P.; et al. MuSK IgG4 autoantibodies cause myasthenia gravis by inhibiting binding between MuSK and Lrp4. Proc. Natl. Acad. Sci. USA 2013, 110, 20783-20788. [CrossRef] [PubMed]

8. Shen, S.; Lu, Y.; Zhang, B.; Figueiredo, D.; Bean, J.; Jung, J.; Wu, H.; Barik, A.; Yin, D.M.; Xiong, W.C. Antibodies against low-density lipoprotein receptor-related protein 4 induce myasthenia gravis. J. Clin. Investig. 2013, 123, 5190-5202. [CrossRef] [PubMed]

9. Plomp, J.J.; Morsch, M.; Phillips, W.D.; Verschuuren, J.J. Electrophysiological analysis of neuromuscular synaptic function in myasthenia gravis patients and animal models. Exp. Neurol. 2015, 270, 41-54. [CrossRef] [PubMed]

10. Verschuuren, J.; Strijbos, E.; Vincent, A. Neuromuscular junction disorders. Handb. Clin. Neurol. 2016, 133, 447-466. [PubMed]

11. Stiegler, A.L.; Burden, S.J.; Hubbard, S.R. Crystal structure of the frizzled-like cysteine domain of the receptor tyrosine kinase MuSK. J. Mol. Biol. 2009, 393, 1-9. [CrossRef] [PubMed]

12. Zhang, B.; Liang, C.; Bates, R.; Yin, Y.; Xiong, W.C.; Mei, L. Wnt proteins regulate acetylcholine receptor clustering in muscle cells. Mol. Brain 2012, 5, 7. [CrossRef] [PubMed]

13. Koles, K.; Nunnari, J.; Korkut, C.; Barria, R.; Brewer, C.; Li, Y.; Leszyk, J.; Zhang, B.; Budnik, V. Mechanism of evenness interrupted (Evi)-exosome release at synaptic boutons. J. Biol. Chem. 2012, 287, 16820-16834. [CrossRef] [PubMed]

14. Jing, L.; Lefebvre, J.L.; Gordon, L.R.; Granato, M. Wnt signals organize synaptic prepattern and axon guidance through the zebrafish unplugged/MuSK receptor. Neuron 2009, 61, 721-733. [CrossRef] [PubMed]

15. Henriquez, J.P.; Salinas, P.C. Dual roles for Wnt signaling during the formation of the vertebrate neuromuscular junction. Acta Physiol. 2012, 204, 128-136. [CrossRef] [PubMed]

16. Strochlic, L.; Falk, J.; Goillot, E.; Sigoillot, S.; Bourgeois, F.; Delers, P.; Rouviere, J.; Swain, A.; Castellani, V.; Schaeffer, L.; et al. Wnt4 participates in the formation of vertebrate neuromuscular junction. PLoS ONE 2012, 7, e29976. [CrossRef] [PubMed]

17. Koles, K.; Budnik, V. Wnt signaling in neuromuscular junction development. Cold Spring Harb. Perspect. Biol. 2012, 4, a008045. [CrossRef] [PubMed]

18. Luo, Z.G.; Wang, Q.; Zhou, J.Z.; Wang, J.; Luo, Z.; Liu, M.; He, X.; Wynshaw-Boris, A.; Xiong, W.C.; Lu, B.; et al. Regulation of AChR clustering by dishevelled interacting with MuSK and PAK1. Neuron 2002, 35, 489-505. [CrossRef]

19. Stiegler, A.L.; Burden, S.J.; Hubbard, S.R. Crystal structure of the agrin-responsive immunoglobulin-like domains 1 and 2 of the receptor tyrosine kinase MuSK. J. Mol. Biol. 2006, 364, 424-433. [CrossRef] [PubMed]

20. Zhang, W.; Coldefy, A.S.; Hubbard, S.R.; Burden, S.J. Agrin binds to the N-terminal region of Lrp4 protein and stimulates association between Lrp4 and the first Ig-like domain in muscle-specific kinase (MuSK). J. Biol. Chem. 2011, 286, 40624-40630. [CrossRef] [PubMed]

21. Zong, Y.; Zhang, B.; Gu, S.; Lee, K.; Zhou, J.; Yao, G.; Figueiredo, D.; Perry, K.; Mei, L.; Jin, R. Structural basis of agrin-Lrp4-MuSK signaling. Genes Dev. 2012, 26, 247-258. [CrossRef] [PubMed]

22. Zong, Y.; Jin, R. Structural mechanisms of the agrin-Lrp4-MuSK signaling pathway in neuromuscular junction differentiation. Cell. Mol. Life Sci. 2013, 70, 3077-3088. [CrossRef] [PubMed]

23. Linnoila, J.; Wang, Y.; Yao, Y.; Wang, Z.Z. A mammalian homolog of Drosophila tumorous imaginal discs, Tid1, mediates agrin signaling at the neuromuscular junction. Neuron 2008, 60, 625-641. [CrossRef] [PubMed]

24. Luo, S.; Zang, B.; Dong, X.P.; Tao, Y.; Ting, A.; Zhou, Z.; Meixiong, J.; Luo, J.; Chiu, F.C.; Mei, L. HSP90 $\beta$ regulates rapsyn turnover and subsequent AChR cluster formation and maintenance. Neuron 2008, 60, 97-110. [CrossRef] [PubMed]

25. Weatherbee, S.D.; Anderson, K.V.; Niswander, L.A. LDL-receptor-related protein 4 is crucial for formation of the neuromuscular junction. Development 2006, 133, 4993-5000. [CrossRef] [PubMed] 
26. Zang, B.; Luo, S.; Wang, Q.; Suzuki, T.; Xiong, W.C.; Mei, L. Lrp4 serves as a coreceptor for agrin. Neuron 2008, 60, 285-297. [CrossRef] [PubMed]

27. Kim, N.; Stiegler, A.L.; Cameron, T.O.; Hallock, P.T.; Gomez, A.M.; Huang, J.H.; Hubbard, S.R.; Dustin, M.L.; Burden, S.J. Lrp4 is a receptor for agrin and forms a complex with MuSK. Cell 2008, 135, 334-342. [CrossRef] [PubMed]

28. Barik, A.; Zhang, B.; Sohal, G.S.; Xiong, W.C.; Mei, L. Crosstalk between agrin and Wnt signaling pathways in development of vertebrate neuromuscular junction. Dev. Neurobiol. 2014, 74, 828-838. [CrossRef] [PubMed]

29. Stamatakou, E.; Salinas, P.C. Postsynaptic assembly: A role for Wnt signaling. Dev. Neurobiol. 2014, 74, 818-827. [CrossRef] [PubMed]

30. Ohkawara, B.; Cabrera-Serrano, M.; Nakata, T.; Milon, M.; Asai, N.; Ito, K.; Ito, M.; Masuda, A.; Ito, Y.; Engel, A.G.; et al. Lrp4 third $\beta$-propeller domain mutations cause novel congenital myasthenia by compromising agrin-mediated MuSK signaling in a position-specific manner. Human Mol. Genet. 2014, 23, 1856-1868. [CrossRef] [PubMed]

31. Wang, J.; Jing, Z.; Zhang, L.; Zhou, G.; Braun, J.; Yao, Y.; Wang, Z.Z. Regulation of acetylcholine receptor clustering by the tumor suppressor APC. Nat. Neurosci. 2003, 6, 1017-1018. [CrossRef] [PubMed]

32. Constantin, B. Dystrophin complex functions as a scaffold for signaling proteins. Biochem. Biophys. Acta 2014, 1838, 635-642. [CrossRef] [PubMed]

33. Hochenester, E.; Yurchenco, P.D. Laminins in basement membrane assembly. Cell Adh. Migr. 2013, 7, $56-63$. [CrossRef] [PubMed]

34. Yurchenco, P.D. Basement membranes: Cell scaffoldings and signaling platforms. Cold Spring Harb. Perspect. Biol. 2011, 3, a004911. [CrossRef] [PubMed]

35. Singhal, N.; Martin, P.T. Role of extracellular matrix proteins and their receptors in the development of the vertebrate neuromuscular junction. Dev. Neurobiol. 2011, 71, 982-1005. [CrossRef] [PubMed]

36. Pilgram, G.S.K.; Potikanond, S.; Baines, R.A.; Fradkin, L.G.; Noordemeer, J.N. The roles of the dystrophin-associated glycoprotein complex at the synapse. Mol. Neurobiol. 2010, 41, 1-21. [CrossRef] [PubMed]

37. Karmouch, J.; Dobbertin, A.; Sigoillot, S.; Legay, C. Developmental consequences of the Col Q/MuSK interactions. Chem. Biol. Interact. 2013, 203, 287-291. [CrossRef] [PubMed]

38. Amenta, A.R.; Creely, H.E.; Mercado, M.L.; Hagiwara, H.; McKechnie, B.A.; Lechner, B.E.; Rossi, S.G.; Wang, Q.; Owens, R.T.; Marrero, E.; et al. Biglycan is an extracellular MuSK binding protein important for synapse stability. J. Neurosci. 2012, 32, 2324-2334. [CrossRef] [PubMed]

39. Nastase, M.V.; Young, M.F.; Schaefer, L. Biglycan: A multivalent proteoglycan providing structure and signals. J. Histochem. Cytochem. 2012, 60, 963-975. [CrossRef] [PubMed]

40. Madhavan, R.; Gong, Z.L.; Ma, J.J.; Chan, A.W.S.; Peng, H.B. The function of cortactin in the clustering of acetylcholine receptors at the vertebrate neuromuscular junction. PLoS ONE 2009, 4, e8478. [CrossRef] [PubMed]

41. Carson, S.S.; Valdez, G.; Sanes, J.R. Presynaptic calcium channels and $\alpha 3$-integrins are complexed with synaptic cleft laminins, cytoskeletal elements and active zone components. J. Neurochem. 2010, 115, 654-666. [CrossRef] [PubMed]

42. Nishimune, H. Molecular mechanism of active zone organization at vertebrate neuromuscular junctions. Mol. Neurobiol. 2012, 45, 1-16. [CrossRef] [PubMed]

43. Samuel, M.A.; Valdez, G.; Tapia, J.C.; Lichtman, J.W.; Sanes, J.R. Agrin and synaptic laminin are required to maintain adult neuromuscular junctions. PLoS ONE 2012, 7, e46663. [CrossRef] [PubMed]

44. Rogers, R.S.; Nishimune, H. The role of laminins in the organization and function of neuromuscular junctions. Matrix Biol. 2017, 57, 86-105. [CrossRef] [PubMed]

45. Simeone, L.; Straubinger, M.; Khan, M.A.; Nalleweg, N.; Cheusova, T.; Hashemolhosseini, S. Identification of Erbin interlinking MuSK and ErbB2 and its impact on acetylcholine receptor aggregation at the neuromuscular junction. J. Neurosci. 2012, 30, 6620-6634. [CrossRef] [PubMed]

46. Ngo, S.T.; Cole, R.N.; Sunn, N.; Phillips, W.D.; Noakes, P.G. Neuregulin-1 potentiates agrin-induced acetylcholine receptor clustering through muscle-specific kinase phosphorylation. J. Cell Sci. 2012, 125 Pt 6 , 1531-1543. [CrossRef] [PubMed] 
47. Schmidt, N.; Akaaboune, M.; Gajendran, N.; Martinez-Pena y Valenzuela, I.; Wakefield, S.; Thurnheer, R.; Brenner, H.R. Neuregulin/ErbB regulate neuromuscular junction development by phosphorylation of

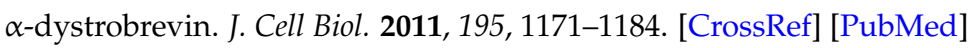

48. Okada, K.; Inoue, A.; Okada, M.; Murata, Y.; Kakuta, S.; Jigami, T.; Kubo, S.; Shiraishi, H.; Eguchi, K.; Motomura, M.; et al. The muscle protein Dok-7 is essential for neuromuscular synaptogenesis. Science 2006, 312, 1802-1805. [CrossRef] [PubMed]

49. Bergamin, E.; Hallock, P.T.; Burden, S.J.; Hubbard, S.R. The cytoplasmic adaptor protein Dok7 activates the receptor tyrosine kinase MuSK via dimerization. Mol. Cell 2010, 39, 100-109. [CrossRef] [PubMed]

50. Hallock, P.T.; Xu, C. F.; Park, T.J.; Neubert, T.A.; Curran, T.; Burden, S.J. Dok7 regulates neuromuscular synapse formation by recruiting Crk and Crk-L. Genes Dev. 2010, 24, 2451-2461. [CrossRef] [PubMed]

51. Hallock, P.T.; Chin, S.; Blais, S.; Neubert, T.A.; Glass, D.J. Sorbs 1 and 2 interact with Crk-L and are required for acetylcholine receptor cluster formation. Mol. Cell. Biol. 2015, 36, 262-270. [PubMed]

52. Wu, H.; Lu, Y.; Barik, A.; Joseph, A.; Taketo, M.M.; Xiong, W.C.; Mei, L. $\beta$-catenin gain of function in muscles impairs neuromuscular junction formation. Development 2012, 139, 2392-2404. [CrossRef] [PubMed]

53. Wu, H.; Barik, A.; Lu, Y.; Shen, C.; Bowman, A.; Li, L.; Sathyamurthy, A.; Lin, T.W.; Xiong, W.C.; Mei, L. Slit2 as a $\beta$-catenin/Ctnnb1-dependent retrograde signal for presynaptic differentiation. eLife 2015, 4, e07266. [CrossRef] [PubMed]

54. Salinas, P.C. Retrograte signaling at the synapse: A role for Wnt proteins. Biochem. Soc. Trans. 2005, 33 Pt 6, 1295-1298. [CrossRef] [PubMed]

55. Südhof, T.C. The presynaptic active zone. Neuron 2012, 75, 11-25. [CrossRef] [PubMed]

56. Tian, X.; Wu, C. Active zone stability: Insights from fly neuromuscular junction. Neural Regen. Res. 2015, 10, 677-680. [PubMed]

57. Jung, J.H.; Szule, J.A.; Marshall, R.M.; McMahan, U.J. Variable priming of a docked synaptic vesicle. Proc. Natl. Acad. Sci. USA 2016, 113, E1098-E1107. [CrossRef] [PubMed]

58. Körber, C.; Kuner, T. Molecular machines regulating the release probability of synaptic vesicles at the active zone. Front. Synaptic Neurosci. 2016, 8, 5. [CrossRef] [PubMed]

59. Harris, K.P.; Littleton, J.T. Transmission, development, and plasticity of synapses. Genetics 2015, 201, 345-375. [CrossRef] [PubMed]

60. Yumoto, N.; Kim, N.; Burden, S.J. Lrp4 is a retrograde signal for presynaptic differentiation at neuromuscular synapses. Nature 2012, 489, 438-442. [CrossRef] [PubMed]

61. Wu, H.; Lu, Y.; Shen, C.; Patel, N.; Gan, L.; Xiong, W.C.; Mei, L. Distinct roles of muscle and motoneuron Lrp4 in neuromuscular junction formation. Neuron 2012, 75, 94-107. [CrossRef] [PubMed]

62. Takamori, M. Lambert-Eaton myasthenic syndrome: Search for alternative autoimmune targets and possible compensatory mechanisms based on presynaptic calcium homeostasis. J. Neuroimmunol. 2008, 201-202, 145-152. [CrossRef] [PubMed]

63. Wang, T.; Jones, R.T.; Whippen, J.M.; Davis, G.W. $\alpha 2 \delta-3$ is required for rapid transsynaptic homeostatic signaling. Cell Rep. 2016, 16, 2875-2888. [CrossRef] [PubMed]

64. Yang, J.; Dominguez, B.; de Winter, F.; Gould, T.W.; Eriksson, J.E.; Lee, K.F. Nestin negatively regulates postsynaptic differentiation of the neuromuscular synapse. Nat. Neurosci. 2011, 14, 324-330. [CrossRef] [PubMed]

65. Takamori, M.; Nakamura, T.; Motomura, M. Antibodies against Wnt receptor of muscle-specific tyrosine kinase in myasthenia gravis. J. Neuroimmunol. 2013, 254, 183-186. [CrossRef] [PubMed]

66. Huijbers, M.G.; Vink, A.F.D.; Niks, E.H.; Westhuis, R.H.; van Zwet, E.W.; de Meel, R.H.; Rojas-Garcia, R.; Diaz-Manera, J.; Kuks, J.B.; Klooster, R.; et al. Longitudinal epitope mapping in MuSK myasthenia gravis: Implications for disease severity. J. Neuroimmunol. 2016, 291, 82-88. [CrossRef] [PubMed]

67. Otsuka, K.; Ito, M.; Ohkawara, B.; Masuda, B.; Kawakami, Y.; Sahashi, K.; Nishida, H.; Mabuchi, N.; Takano, A.; Engel, A.G.; et al. Collagen $Q$ and anti-MuSK autoantibody competitively suppress agrin/Lrp4/MuSK signaling. Sci. Rep. 2015, 5, 13928-13939. [CrossRef] [PubMed]

68. Messéant, J.; Dobbertin, A.; Girard, E.; Delers, P.; Manuel, M.; Mangione, F.; Schmitt, A.; Le Denmat, D.; Molgó, J.; Zytnichi, D.; et al. MuSK Frizzled-like domain is critical for mammalian neuromuscular junction formation and maintenance. J. Neurosci. 2015, 35, 4926-4941. [CrossRef] [PubMed] 
69. Remédio, L.; Gribble, K.D.; Lee, J.K.; Kim, N.; Hallock, P.T.; Delestrée, N.; Mentis, G.Z.; Froemke, R.C.; Granato, M.; Burden, S.J. Diverging roles for Lrp4 and Wnt signaling in neuromuscular synapse development during evolution. Genes Dev. 2016, 30, 1058-1069. [CrossRef] [PubMed]

70. Kawakami, Y.; Ito, M.; Hirayama, M.; Sahashi, K.; Ohkawara, B.; Masuda, A.; Nishida, H.; Mabuchi, N.; Engel, A.G.; Ohno, K. Anti-MuSK autoantibodies block binding of collagen Q to MuSK. Neurology 2011, 77, 1819-1826. [CrossRef] [PubMed]

71. Cartaudo, A.; Strochlic, L.; Guerra, M.; Blanchard, B.; Lambergeon, M.; Krejci, E.; Cartaud, J.; Legay, C. MuSK is required for anchoring acetylcholinesterase at the neuromuscular junction. J. Cell Biol. 2004, 165, 505-515. [CrossRef] [PubMed]

72. Liu, Y.; Padgett, D.; Takahashi, M.; Li, H.; Sayeed, A.; Teichert, R.W.; Olivera, B.M.; McArdle, J.J.; Green, W.N.; Lin, W. Essential roles of the acetylcholine receptor $\gamma$-subunit in neuromuscular synaptic patterning. Development 2008, 135, 1957-1967. [CrossRef] [PubMed]

73. Hacohen, Y.; Jacobson, L.W.; Byrne, S.; Norwood, F.; Lall, A.; Robb, S.; Dilena, R.; Fumagalli, M.; Born, A.P.; Clarke, D.; et al. Fetal acetylcholine receptor inactivation syndrome. A myopathy due to maternal antibodies. Neurol. Neuroimmunol. Neuroinflamm. 2015, 2, e57. [CrossRef] [PubMed]

74. Chen, F.; Liu, Y.; Sugiura, Y.; Allen, P.D.; Gregg, R.G.; Lin, W. Neuromuscular synaptic patterning requires the function of skeletal muscle dihydropyridine receptors. Nat. Neurosci. 2011, 14, 570-577. [CrossRef] [PubMed]

75. Maruta, T.; Yoshikawa, H.; Fukasawa, S.; Umeshita, S.; Inaoka, Y.; Edahiro, S.; Kado, H.; Motozaki, Y.; Iwasa, K.; Yamada, M. Autoantibody to dihydropyridine receptor in myasthenia gravis. J. Neuroimmunol. 2009, 208, 125-129. [CrossRef] [PubMed]

76. Niks, E.H.; Kuks, J.B.; Wokke, J.H.; Verdman, H.; Bakker, E.; Vershuuren, J.J.; Plomp, J.J. Pre- and postsynaptic neuromuscular junction abnormalities in MuSK myasthenia. Muscle Nerve 2010, 42, 283-288. [CrossRef] [PubMed]

77. Davis, G.W.; Müller, M. Homeostatic control of presynaptic neurotransmitter release. Annu. Rev. Physiol. 2015, 77, 251-270. [CrossRef] [PubMed]

78. Wang, X.; Pinter, M.J.; Rich, M.M. Reversible recruitment of a homeostatic reserve pool of synaptic vesicles underlies rapid homeostatic plasticity of quantal content. J. Neurosci. 2016, 36, 828-836. [CrossRef] [PubMed]

79. Oliveira, L.; Timóteo, M.A.; Correia-de-Sá, P. Modulation by adenosine of both muscarinic $\mathrm{M}_{1}$-facilitation and M2-inhibition of $[3 \mathrm{H}]$-acetylcholine release from the rat motor nerve terminals. Eur. J. Neurosci. 2002, 15, 1728-1736. [CrossRef] [PubMed]

80. Oliveira, L.; Correia-de-Sá, P. Protein kinase A and $\mathrm{Ca}_{\mathrm{v}} 1$ (L-Type) channels are common targets to facilitatory adenosine $A_{2 A}$ and muscarinic $M_{1}$ receptors on rat motoneurons. Neurosignals 2005, 14, 262-272. [CrossRef] [PubMed]

81. Oliveira, L.; Timóteo, M.A.; Correira-de-Sá, P. Negative crosstalk between $\mathrm{M}_{1}$ and $\mathrm{M}_{2}$ muscarinic autoreceptors involves endogeneous adenosine activating $\mathrm{A}_{1}$ receptors at the rat motor endplate. Neurosci. Lett. 2009, 459, 127-131. [CrossRef] [PubMed]

82. Correira-de-Sá, P.; Timóteo, M.A.; Ribeiro, J.A. Presynaptic $A_{1}$ inhibitory/ $A_{2 A}$ facilitatory adenosine receptor activation balance depends on motor nerve stimulation paradigm at the rat hemidiaphragm. J. Neurophysiol. 1996, 76, 3910-3919.

83. Oliveira, L.; Timóteo, M.A.; Correia-de-Sá, P. Tetanic depression is overcome by tonic adenosine $\mathrm{A}_{2 \mathrm{~A}}$ receptor facilitation of L-type $\mathrm{Ca}^{2+}$ influx into rat motor nerve terminals. J. Physiol. 2004, 560 Pt 1, 157-168. [CrossRef] [PubMed]

84. Oliveira, L.; Costa, A.C.; Noronha-Matos, J.B.; Silva, I.; Cavalcante, W.L.; Timóteo, M.A.; Corrado, A.P.; del Belo, C.A.; Ambiel, C.R.; Alves-do-Prado, W.; et al. Amplification of neuromuscular transmission by methylprednisolone involves activation of presynaptic facilitatory adenosine $A_{2 A}$ receptors and redistribution of synaptic vesicles. Neuropharmacology 2015, 89, 64-76. [CrossRef] [PubMed]

85. Noronha-Matos, J.B.; Morais, T.; Trigo, D.; Timóteo, M.A.; Magalhăes-Cardoso, M.T.; Oliveira, L.; Correia-de-Sá, P. Tetanic failure due to decreased endogeneous adenosine $\mathrm{A}_{2 \mathrm{~A}}$ tonus operating neuronal $\mathrm{Ca}_{\mathrm{v}} 1$ (L-Type) influx in myasthenia gravis. J. Neurochem. 2011, 117, 797-811. [CrossRef] [PubMed] 
86. Oliveira, L.; Correia, A.; Cristina-Costa, A.; Guerra-Gomes, S.; Ferreirinha, F.; Magalhăes-Cardoso, M.T.;

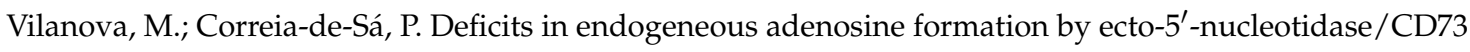
impair neuromuscular transmission and immune competence in experimental autoimmune myasthenia gravis. Mediators Inflamm. 2015, 2015, 460610. [CrossRef] [PubMed]

87. Zhang, B.; Shen, C.; Bealmear, B.; Ragheb, S.; Xiong, W.C.; Lewis, R.A.; Lisak, R.P.; Mei, L. Autoantibodies to agrin in myasthenia gravis patients. PLoS ONE 2014, 9, e91816. [CrossRef] [PubMed]

88. Gasperi, C.; Meles, A.; Schoser, B.; Zhang, Y.; Meltoranta, J.; Risson, V.; Schaeffer, L.; Schalke, B.; Kröger, S. Anti-agrin autoantibodies in myastyhenia gravis. Neurology 2014, 82, 1976-1983. [CrossRef] [PubMed]

89. Gesemann, M.; Denzer, A.J.; Ruegg, M.A. Acetylcholine receptor-aggregating activity of agrin isoforms and mapping of the active state. J. Cell Biol. 1995, 128, 625-636. [CrossRef] [PubMed]

90. Scotton, P.; Bleckmann, D.; Stebler, M.; Sciandra, F.; Brancaccio, A.; Meier, T.; Stetefeld, J.; Ruegg, M.A. Activation of muscle-specific receptor tyrosine kinase and binding to dystroglycan are regulated by alternative mRNA splicing of agrin. J. Biol. Chem. 2006, 281, 36835-36845. [CrossRef] [PubMed]

91. Tezuka, T.; Inoue, A.; Hoshi, T.; Wheatherbee, S.D.; Buraes, R.W.; Ueta, R. The MuSK activator agrin has a separate role essential for postnatal maintenance of neuromuscular synapses. Proc. Natl. Acad. Sci. USA 2014, 111, 16556-16561. [CrossRef] [PubMed]

92. Zhang, B.G.; Quigley, A.F.; Bourke, J.L.; Nowell, C.J.; Myers, D.E.; Choong, P.F.; Kapsa, R.M. Combination of agrin and laminin increase acetylcholine receptor clustering and enhance functional neuromuscular junction formation in vitro. Dev. Neurobiol. 2015, 76, 551-565. [CrossRef] [PubMed]

93. Patel, T.R.; Butler, G.; McFarlane, A.; Xie, I.; Overall, C.M.; Stetefeld, J. Site specific cleavage mediated by MMPs regulates function of agrin. PLoS ONE 2012, 7, e43669. [CrossRef] [PubMed]

94. Luckman, S.P.; Gilhus, N.E.; Romi, F. Matrix metalloproteinase-3 in myasthenia gravis compared to other neurological disorders and healthy controls. Autoimmune Dis. 2011, 2011, 151258. [CrossRef] [PubMed]

95. Molin, C.J.; Weaterberg, E.; Punga, A.R. Profile of upregulated inflammatory proteins in sera of myasthenia gravis patients. Sci. Rep. 2017, 7, 39716. [CrossRef] [PubMed]

96. Todd, K.; Auld, D.S.; Robitaille, R. Neurotrophins modulate neuron-glia interactions at a vertebrate synapse. Eur. J. Neurosci. 2007, 25, 1287-1296. [CrossRef] [PubMed]

97. Fenz, Z.; Ko, C.P. Schwann cells promote synaptogenesis at the neuromuscular junction via transforming growth factor- $\beta 1$. J. Neurosci. 2008, 28, 9599-9609.

98. Amaral, M.D.; Pozzo-Miller, L. Intracellular $\mathrm{Ca}^{2+}$ stores and $\mathrm{Ca}^{2+}$ influx are both required for BDNF to rapidly increase quantal vesicular transmitter release. Neural. Plast. 2012, 2012, 203536. [CrossRef] [PubMed]

99. Yi, H.; Hu, J.; Quian, J.; Hackam, A.S. Expression of brain-derived neurotrophic factor is regulated by the Wnt signaling pathway. Neuroreports 2012, 23, 189-194. [CrossRef] [PubMed]

100. Bartus, R.T.; Bétourné, A.; Basile, A.; Peterson, B.L.; Glass, J.; Boulís, N.M. $\beta 2$-adrenoceptor agonists as novel, safe and potentially effective therapies for amyotrophic lateral sclerosis (ALS). Neurobiol. Dis. 2015, 85, 11-24. [CrossRef] [PubMed]

101. Ghazanfari, N.; Morsch, M.; Tse, N.; Reddel, S.W.; Phillips, W.D. Effects of the $\beta 2$-adrenoceptor agonist, alubuterol, in a mouse model of anti-MuSK myasthenia gravis. PLoS ONE 2014, 9, e87840. [CrossRef] [PubMed]

102. Allen, N.M.; Hacohen, Y.; Palace, J.; Beeson, D.; Vincent, A.; Jungbluth, H. Salbutamol-responsive fetal acetylcholine receptor inactivation syndrome. Neurology 2016, 86, 692-694. [CrossRef] [PubMed]

103. Lipka, A.F.; Vrinten, C.; van Zwet, E.W.; Schimmel, K.J.; Cornel, M.C.; Kuijpers, M.R.; Hekster, Y.A.; Weinreich, S.S.; Verschuuren, J.J. Ephedrine treatment for autoimmune myasthenia gravis. Neuromuscul. Disord. 2017, 27, 259-265. [CrossRef] [PubMed]

104. Engel, A.G.; Shen, X.M.; Selcen, D.; Sine, S.M. Congenital myasthenic syndromes: Pathogenesis, diagnosis, and treatment. Lancet Neurol. 2015, 144, 420-434. [CrossRef]

105. Beeson, D. Congenital myasthenic syndromes: Recent advances. Curr. Opin. Neurol. 2016, $29,565-571$. [CrossRef] [PubMed]

106. Gallenmüller, C.; Müller-Felber, W.; Dusl, M.; Stucka, R.; Guergueltcheva, V.; Blaschek, A.; von der Hagen, M.; Huebner, A.; Müller, J.S.; Lochmüller, H.; et al. Sulbutamol-responsive limb-girdle congenital myasthenic syndrome due to a novel missense mutation and heteroallelic deletion in MuSK. Neuromuscul. Disord. 2014, 24, 31-35. [CrossRef] [PubMed] 
107. Selcen, D.; Ohkawara, B.; Shen, X.M.; McEvoy, K.; Ohno, K.; Engel, A.G. Impaired synaptic development, maintenance, and neuromuscular transmission in Lrp4-related myasthenia. JAMA Neurol. 2015, 72, 889-896. [CrossRef] [PubMed]

108. Gallardo, E.; Martínez-Hernández, E.; Titulaer, M.J.; Huijbers, M.G.; Martínez, M.A.; Ramos, A.; Querol, L.; Díaz-Manera, J.; Rojas-García, R.; Hayworth, C.R.; et al. Cortactin autoantibodies in myasthenia gravis. Autoimmun. Rev. 2014, 13, 1003-1007. [CrossRef] [PubMed]

109. Cortés-Vicente, E.; Gallardo, E.; Martínez, M.Á.; Díaz-Manera, J.; Querol, L.; Rojas-Gracía, R.; Illa, I. Clinical characteristics of patients with double-seronegative myasthenia gravis and antibodies to cortactin. JAMA Neurol. 2016, 73, 1099-1104. [CrossRef] [PubMed]

110. Peng, H.B.; Xie, H.; Dai, Z. Association of cortactin with developing neuromuscular specializations. J. Neurocytol. 1997, 26, 637-650. [CrossRef] [PubMed]

111. Alicea, D.; Perez, M.; Maodonado, C.; Dominicci-Cotto, C.; Marie, B. Cortactin is a regulator of activity-dependent synaptic plasticity controlled by Wingless. J. Neurosci. 2017, 37, 2203-2215. [CrossRef] [PubMed]

112. Chen, Y.; Ip, F.C.F.; Shi, L.; Zhang, Z.; Tang, H.; Ng, Y.P.; Ye, W.C.; Fu, A.K.; Ip, N.Y. Coronin 6 regulates acetylcholine receptor clustering through modulating receptor anchorage to actin cytoskeleton. J. Neurosci. 2014, 34, 2413-2421. [CrossRef] [PubMed]

113. Hezel, M.; de Groat, W.C.; Galbiati, F. Caveolin-3 promotes nicotinic acetylcholine receptor clustering and regulates neuromuscular junction activity. Mol. Biol. Cell 2010, 21, 302-310. [CrossRef] [PubMed]

114. Bourgeois, F.; Messéant, J.; Kordeli, E.; Petit, J.M.; Delers, P.; Bahi-Buisson, N.; Bernard, V.; Sigoillot, S.M.; Gitiaux, C.; Stouffer, M.; et al. A critical and previously unsuspected role for doublecortin at the neuromuscular junction in mouse and human. Neurmuscul. Disord. 2015, 25, 461-473. [CrossRef] [PubMed]

115. Nakashima, H.; Ohkawara, B.; Ishigaki, S.; Fukudome, T.; Ito, K.; Tsushima, M.; Konishi, H.; Okuno, T.; Yoshimura, T.; Ito, M.; et al. R-spondin 2 promotes acetylcholine receptor clustering at the neuromuscular junction via Lrg5. Sci. Rep. 2016, 6, 28512. [CrossRef] [PubMed]

116. Vieira, G.C.; Chockalingam, S.; Melegh, Z.; Greenhough, A.; Malik, S.; Szemes, M.; Park, J.H.; Kaidi, A.; Zhou, L.; Catchpoole, D.; et al. LGR5 regulates pro-survival MEK/ERK and proliferative Wnt/ $\beta$-catenin signalling in neuroblastoma. Oncotarget 2015, 6, 40053-40067. [PubMed]

117. Akaaboune, M.; Allinguant, B.; Farza, H.; Roy, K.; Magoul, R.; Fiszman, M.; Festoff, B.W.; Hantaï, D. Developmental regulation of amyloid precursor protein at the neuromuscular junction in mouse skeletal muscle. Mol. Cell. Neurosci. 2000, 15, 355-367. [CrossRef] [PubMed]

118. Wang, Z.; Wang, B.; Yang, L.; Guo, Q.; Aithmitti, N.; Songyang, Z.; Zheng, H. Pre- and postsynaptic interaction of the amyloid precursor protein promotes peripheral and central synaptogenesis. J. Neurosci. 2009, 29, 10788-10801. [CrossRef] [PubMed]

119. Choi, H.Y.; Liu, Y.; Tennert, C.; Sugiura, Y.; Karakatsani, A.; Kröger, S.; Johnson, E.B.; Hammer, R.E.; Lin, W.; Herz, J. APP interacts with Lrp4 and agrin to coordinate the development of the neuromuscular junction in mice. eLife 2013, 2, e00220. [CrossRef] [PubMed]

120. Caldwell, J.H.; Klevanski, M.; Saar, M.; Müller, U.C. Roles of the amyloid precursor protein family in the peripheral nervous system. Mech. Dev. 2013, 130, 433-446. [CrossRef] [PubMed]

121. Stanga, S.; Zanou, N.; Audouard, E.; Tasiaux, B.; Contino, S.; Vandermeulen, G.; René, F.; Loeffler, J.P.; Clotman, F.; Gailly, P.; et al. APP-dependent glial cell line-derived neurotrophic factor gene expression drives neuromuscular junction. FASEB J. 2016, 30, 1696-1711. [CrossRef] [PubMed]

122. Baudet, C.; Pozas, E.; Adameyko, I.; Andersson, E.; Ericson, J.; Ernfors, P. Retrograde signaling onto Ret during motor nerve terminal maturation. J. Neurosci. 2008, 28, 963-975. [CrossRef] [PubMed]

123. Südhof, T.C. Neuroligins and neurexins link synaptic function to cognitive disease. Nature 2008, 455, $903-911$. [CrossRef] [PubMed]

(C) 2017 by the author. Licensee MDPI, Basel, Switzerland. This article is an open access article distributed under the terms and conditions of the Creative Commons Attribution (CC BY) license (http:/ / creativecommons.org/licenses/by/4.0/). 